\title{
Three cases of the hemoglobin G-Chinese variant detected in patients of southern Chinese origin
}

\author{
PENG-PENG WANG ${ }^{1}$, MIN LIN ${ }^{1}$, JIAO-REN WU ${ }^{1}$, XIAN-YAO WANG ${ }^{2}$ and LI-YE YANG ${ }^{1}$ \\ ${ }^{1}$ Central Laboratory, Chaozhou Central Hospital, Chaozhou 521021; ${ }^{2}$ Department of Pediatrics, \\ Shantou Central Hospital, Shantou 515041, P.R. China
}

Received January 4, 2010; Accepted February 16, 2010

DOI: $10.3892 / \mathrm{mmr} 00000280$

\begin{abstract}
Hemoglobin (Hb) G-Chinese [a30 (B11) $\mathrm{Glu} \rightarrow \mathrm{Gln}$ ], also known as $\mathrm{Hb}$ G-Honolulu, Hb G-Hongkong or $\mathrm{Hb}$ G-Singapore, was first identified in a Chinese woman in Singapore, and was subsequently observed in several Chinese families. This $\mathrm{Hb}$ variant results from a $\mathrm{GAG} \rightarrow \mathrm{CAG}$ mutation at codon 30 of the $\alpha$-globin gene. The aim of the present study was to identify the $\mathrm{Hb}$ G-Chinese mutation in three Cantonese individuals. The presence of the $\mathrm{Hb}$ variant was confirmed by cellulose acetate electrophoresis. DNA analysis based on the polymerase chain reaction (PCR) and sequencing were conducted to confirm the presence of the mutation in the $\alpha$-globin gene. $\mathrm{A} \mathrm{G} \rightarrow \mathrm{C}$ substitution at codon 30 of the $\alpha_{2}$-globin gene was observed. According to a previous study, the $\mathrm{G} \rightarrow \mathrm{C}$ substitution in $\mathrm{Hb}$ G-Chinese creates a Pst restriction site; we amplified the $\alpha_{2}$-globin gene, then digested the PCR products with PstI. The results indicated that only the PCR product of $\mathrm{Hb}$ G-Chinese $\alpha_{2}$-globin was cut by PstI. The digestive products were 120 and $730 \mathrm{bp}$, respectively. Therefore, we determined that the three cases were of the heterozygous $\mathrm{Hb}$ G-Chinese variant.
\end{abstract}

\section{Introduction}

Hemoglobin (Hb) G-Chinese $\left[\begin{array}{lll}\alpha 30 & \text { (B11) Glu } \rightarrow \mathrm{Gln}\end{array}\right]$, also known as $\mathrm{Hb}$ G-Honolulu, $\mathrm{Hb}$ G-Hongkong and $\mathrm{Hb}$ G-Singapore, was first identified in a Chinese woman in Singapore by Vella et al in 1958 (1), and was subsequently observed in several Chinese families $(2,3)$. This $\mathrm{Hb}$ variant results from a $\mathrm{GAG} \rightarrow \mathrm{CAG}$ mutation at codon 30 of the $\alpha$-globin gene. $\mathrm{Hb} \mathrm{G}$-Chinese carriers do not present the clinical symptoms or hematological changes often observed in thalassemia screening. Almost all previous reports identified the $\mathrm{Hb}$ G-Chinese variant in Chinese families from Singapore, Taiwan, Honolulu and Hong Kong (1-4). To the

Correspondence to: Dr Li-Ye Yang, Central Laboratory, Chaozhou Central Hospital, Chaozhou 521021, Guangdong, P.R. China

E-mail: yangleeyee@sina.com

Key words: hemoglobin variant, hemoglobin G-Chinese best of our knowledge, only two reported cases involved individuals from mainland China $(5,6)$, and in these reports the diagnoses were made using amino acid chemical structural analysis, with no detailed information provided regarding the globin gene. There have been no reports on the $\mathrm{Hb}$ G-Chinese variant in mainland China in the English literature.

According to the results of hemoglobin electrophoresis, $\mathrm{Hb}$ G-Chinese is a slow-moving hemoglobin variant with a total hemoglobin concentration of $12-15 \%$ (1-8) that migrates towards the anode faster than $\mathrm{Hb} \mathrm{S}$ and more slowly than $\mathrm{Hb}$ A upon cellulose acetate electrophoresis (9). While conducting recent screening for thalassemia in the Chaozhou area of Guangdong Province, we observed a hemoglobin mutation in three Chinese male individuals, which proved to be a heterozygous $\mathrm{Hb} \mathrm{G}-\mathrm{Chinese}$ variant.

\section{Materials and methods}

Subjects and hematological analysis. We examined three subjects of Han nationality who had an unknown $\mathrm{Hb}$ variant with no clinical manifestations. The subjects were unrelated local residents of the Chaozhou area undergoing screening for anemia as medical outpatients at the Chaozhou Central Hospital, Guangdong, China. EDTA blood samples were taken and immediately sent (at $4^{\circ} \mathrm{C}$ ) to the Hematology and Molecular Laboratory for further analysis. Hematological data were collected on an automated blood cell counter (Abbott Cell-Dyn CD3700; Abbott Laboratories, Illinois, USA). $\mathrm{Hb}$ analysis was carried out by standard cellulose acetate electrophoresis at $\mathrm{pH}$ 8.6. Written informed consent was obtained from all patients prior to their participation in the study.

DNA analysis. Genomic DNA was extracted from peripheral blood leukocytes with the genomic DNA Mini-Preparation kit (Decipher Bioscience Shenzhen Ltd.) as previously described (10). The $\alpha_{2}$-globin gene was amplified by PCR in a DNA Thermal Cycler KP-TC48 (Chaozhou Hybribio Biotechnology, China) with previously described primers (11). The 50- $\mu 1$ PCR reaction mixture contained $0.1 \mu \mathrm{g}$ DNA, 15 pmol primers, $200 \mu$ mol dNTPs and 2.5 units Taq DNA polymerase (Shanghai Sangon Biological Engineering Technology \& Services Co., Ltd., China.) in $10 \mathrm{mmol} / \mathrm{l}$ 
Table I. Summary of the hematological findings of the patients.

\begin{tabular}{lccc}
\hline Parameter & Case 1 & Case 2 & Case 3 \\
\hline Gender & $\mathrm{M}$ & $\mathrm{M}$ & $\mathrm{M}$ \\
$\mathrm{RBC}\left(10^{12}\right)$ & 6.3 & 4.36 & 5.04 \\
$\mathrm{Hb}(\mathrm{g} / \mathrm{l})$ & 176.0 & 133.0 & 152.0 \\
$\mathrm{MCV}(\mathrm{fl})$ & 82.5 & 91.8 & 87.5 \\
$\mathrm{HCT}(\mathrm{l} / \mathrm{l})$ & 0.517 & 0.4 & 0.441 \\
$\mathrm{MCH}(\mathrm{pg})$ & 27.9 & 30.5 & 30.2 \\
$\mathrm{MCHC}(\mathrm{g} / \mathrm{l})$ & 340.0 & 333.0 & 345.0 \\
$\mathrm{RDW}$ & 13.8 & 12.8 & 13.3 \\
$\mathrm{SI}(\mu \mathrm{mol} / \mathrm{l})$ & 22.5 & 17.2 & 11.8 \\
$\mathrm{Hb} \mathrm{A}(\%)$ & 77.9 & 78.3 & 78.9 \\
$\mathrm{Hb} \mathrm{A}(\%)$ & 1.9 & 1.9 & 2.0 \\
Hb G-Chinese $(\%)$ & 20.2 & 19.8 & 19.1 \\
$\alpha-g l o b i n$ gene type & $\alpha \alpha / \alpha \alpha^{\text {Chinese }}$ & $\alpha \alpha / \alpha \alpha^{\text {Chinese }}$ & $\alpha \alpha / \alpha \alpha^{\text {Chinese }}$ \\
\hline
\end{tabular}

$\mathrm{M}$, male; RBC, red blood cells; Hb, hemoglobin; $\mathrm{MCV}$, mean corpuscular volume; HCT, hematocrit; $\mathrm{MCH}$, mean corpuscular hemoglobin; MCHC, mean corpuscular hemoglobin concentration; RDW, red blood cell distribution width; SI, serum iron.

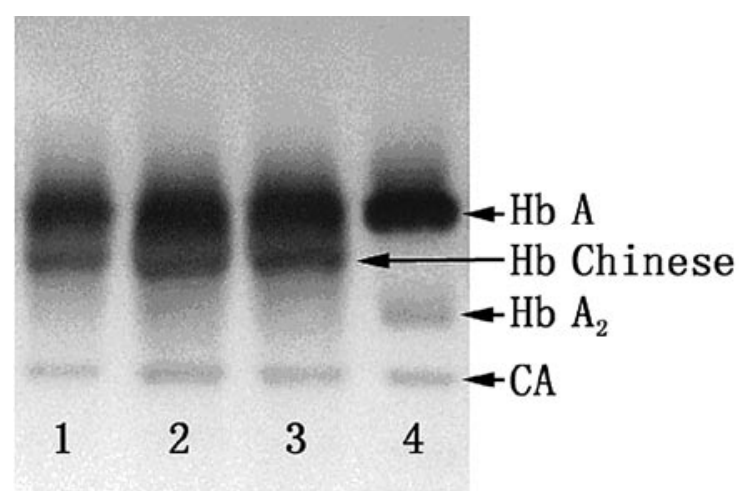

Figure 1. Hemoglobin analysis of the patients with $\mathrm{Hb}$ G-Chinese by cellulose acetate electrophoresis at $\mathrm{pH}$ 8.6. Lanes 1-3, cases 1-3; lane 4, normal control.

Tris- $\mathrm{HCl}(\mathrm{pH} 8.0), 50 \mathrm{mmol} / \mathrm{l} \mathrm{KCl}$ and $3 \mathrm{mmol} / \mathrm{l} \mathrm{MgCl}$. The amplification reaction was carried out in the DNA Thermal Cycler KP-TC48. Initial denaturation was performed at $94^{\circ} \mathrm{C}$ for $3 \mathrm{~min}$, followed by 35 cycles at $94^{\circ} \mathrm{C}$ for $1 \mathrm{~min}$ and $55^{\circ} \mathrm{C}$ for $30 \mathrm{sec}$, followed by a final extension at $72^{\circ} \mathrm{C}$ for $2 \mathrm{~min}$. Amplified products were separated by $2 \%$ agarose gel and detected with UV light following ethidium bromide staining. PCR products were analyzed by DNA sequencing using the ABI 377 DNA Sequencer (Applied Biosystems, CA, USA).

PstI restriction enzyme digestion. According to a previous study, the $\mathrm{G} \rightarrow \mathrm{C}$ substitution found in patients with the $\mathrm{Hb}$ G-Chinese variant creates a PstI restriction site (3). We therefore amplified the $\alpha_{2}$-globin gene, and subsequently digested the PCR products with Pst.

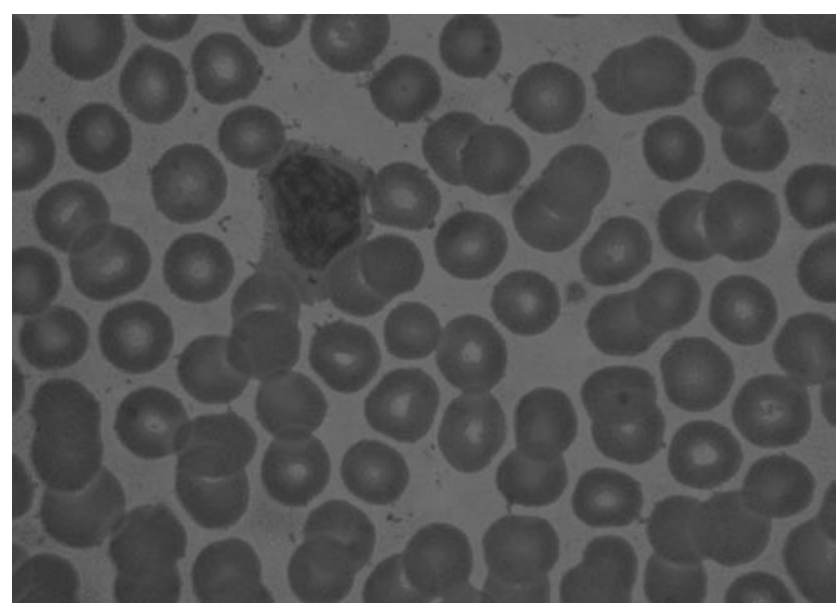

Figure 2. Wright's staining of red blood cells in samples from the patients with the $\alpha_{2}$-globin $\mathrm{Hb}$ G-Chinese gene mutation. Red blood cell morphology was normal. Magnification, x100.

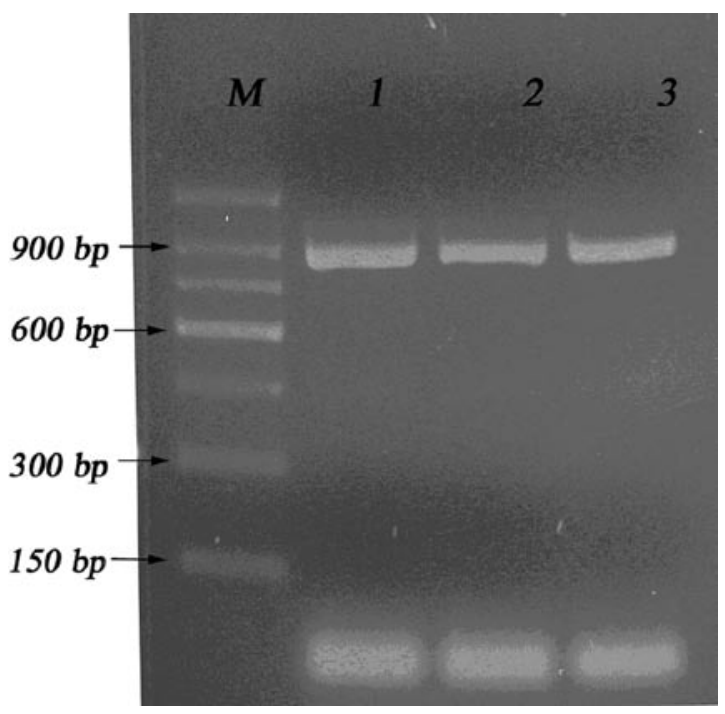

Figure 3. PCR products of $\alpha_{2}$-globin in the patients with the Hb G-Chinese variant. Lane M, maker; lane 1, case 1; lane 2, case 2; lane 3, case 3 .

\section{Results}

The hematological data of the patients are summarized in Table I. A serum iron test showed no iron deficiency. The $\mathrm{Hb}$ variant patterns were revealed by $\mathrm{Hb}$ electrophoresis (Fig. 1). An isopropanol test revealed that the $\mathrm{Hb}$ levels were stable ( $>40 \mathrm{~min})$. The red blood cell morphology of the patients (determined by Wright's staining) was normal (Fig. 2).

The $\alpha_{2}$-globin gene was amplified by PCR, the products of which are shown in Fig. 3. A G $\rightarrow$ C substitution at codon 30 of the $\alpha_{2}$-globin gene was observed (Fig. 4). The three patients were heterozygous for the $\mathrm{Hb}$ G-Chinese variant. The results of PstI digestion indicated that only the PCR product of $\mathrm{Hb}$ G-Chinese $\alpha_{2}$-globin could be cut by PstI. The digestive products were 120 and $730 \mathrm{bp}$, respectively. The PCR product of the wild-type normal control could not be cut, and remained at 850 bp (Fig. 5). 


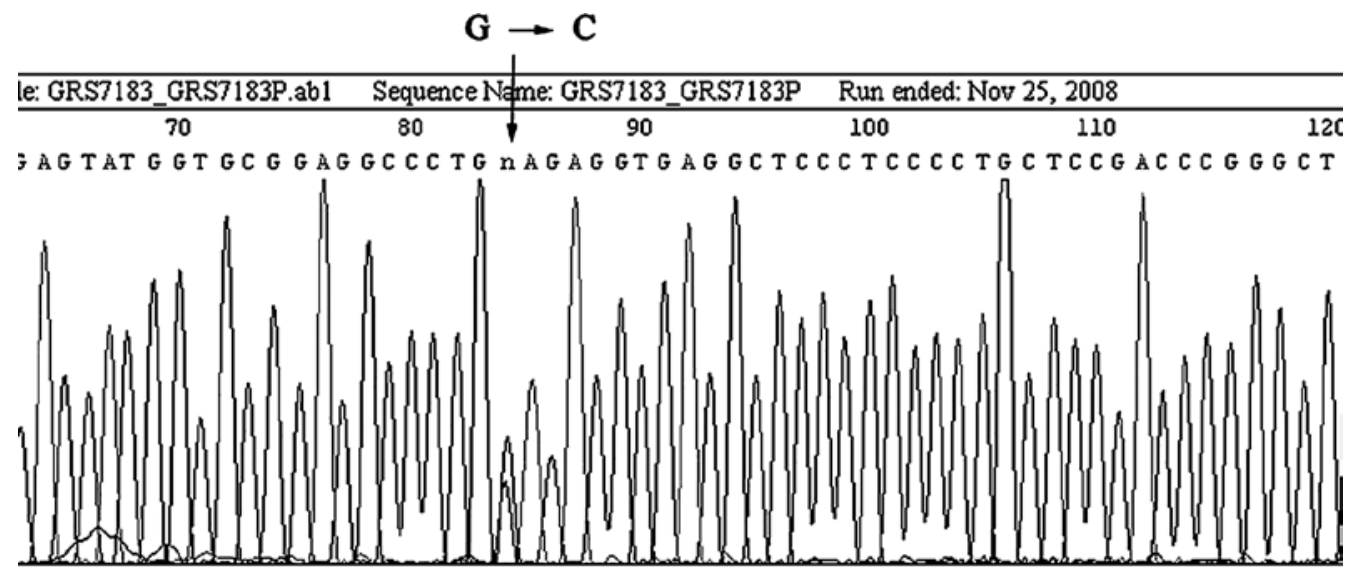

Figure 4. Sequence analysis of the amplified $\alpha_{2}$-globin gene in the patients with the $\mathrm{Hb}$ G-Chinese variant. The downward arrow indicates the G $\rightarrow \mathrm{C}$ substitution at codon 30 of the $\alpha_{2}$-globin gene.

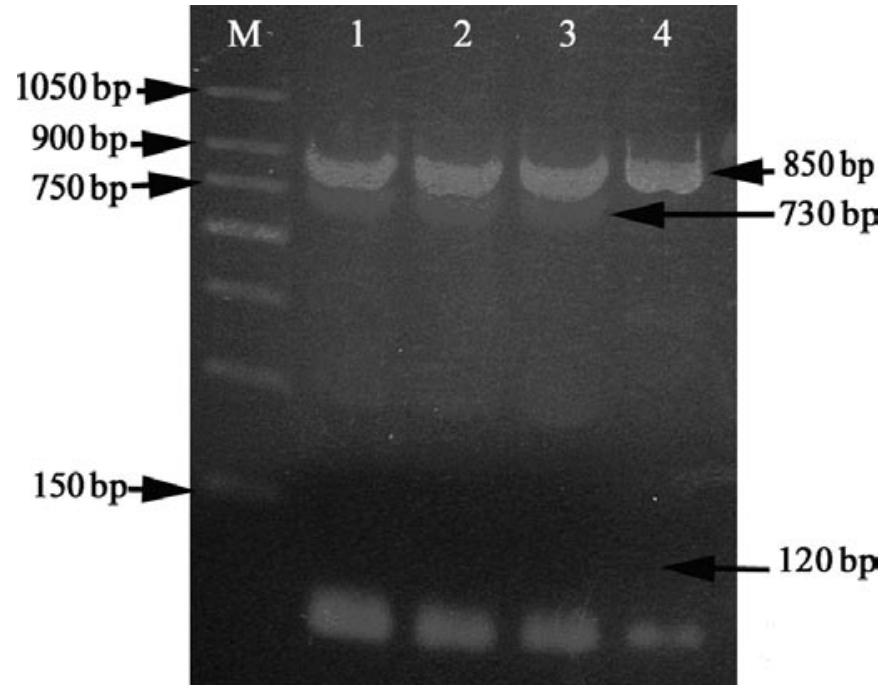

Figure 5. Results of PstI restriction enzyme digestion. The Hb G-Chinese $\alpha_{2}$-globin PCR products have a PstI cutting site (lanes 1, 2 and 3 ), while the wild-type normal control (lane 4) does not. M, 150-bp ladder marker; lanes 1-3, cases 1-3; lane 4, normal control. Due to long-term electrophoresis and DNA diffusion, the 120-bp products were difficult to discern.

\section{Discussion}

A hemoglobin screening carried out 20 years ago in the Chaozhou area of China identified 10 cases of the $\mathrm{Hb} \mathrm{G}$ and D variants among 5,946 individuals studied, a prevalence of $0.168 \%$. Several of these cases may have been of the $\mathrm{Hb}$ G-Chinese variant; however, since nucleic acid determination was not yet available, a positive identification of the variant was not possible (9).

In the present study, we used $\alpha_{2}$-globin gene amplification and PstI restriction enzyme digestion to identify three cases of the $\mathrm{Hb}$ G-Chinese variant, which results from a $\mathrm{GAG} \rightarrow \mathrm{CAG}$ mutation at codon 30 of the $\alpha$-globin gene. All three subjects carrying the mutation were of Han nationality from the Chaozhou area.

Chaozhou is located in the east of Guangdong Province, which is near the southern border of Fujian Province. Residents of Chaozhou trace their ancestry to Fujian. The majority of residents of Taiwan and of other Chinese living overseas are descended from emigrants from southern China, including the Fujian and Canton Provinces. It is therefore likely that the $\mathrm{Hb}$ G-Chinese variant found in Taiwan $(3,7,8)$ is the same as the variant we detected in the individuals from Chaozhou.

\section{Acknowledgements}

This study was supported in part by the Guangdong Province Medical Science Foundation (no. A2009781 to L-Y.Y. and no. B2008179 to M.L.).

\section{References}

1. Vella F, Ager JA and Lehmann H: An abnormal haemoglobin in a Chinese: haemoglobin G. Nature 82: 460-461, 1958.

2. Schneider RG and Jim RT: A new haemoglobin variant (the 'Honolulu type') in a Chinese. Nature 190: 454-455, 1961.

3. Chang JG, Shih MC, Liu SC, Chen CM, Chan WL and Peng CT: Hb G-Chinese: a $\mathrm{G} \rightarrow \mathrm{C}$ substitution at codon 30 of the alpha2globin gene creates a PstI cutting site. Hemoglobin 26: 95-97, 2002.

4. Swenson RT, Hill RL, Lehmann H and Jim RTS: A chemical abnormality in hemoglobin from Chinese individuals. J Biol Chem 237: 1517-1520, 1962.

5. Liu GY, Zhang GX, Nie SY, Luo HY, Tao ZY, Zhang LY, Chen SS, Jia PC and Liang ZC: A case of HbG Chinese found in Henan. Zhongguo Yi Xue Ke Xue Yuan Xue Bao (in Chinese) 6: 48-50, 1984.

6. Zeng YT, Huang SZ, Zhou XD, Feng JP, Chen MY, Qiu XK, Tao YJ and Chen BF: A structural analysis of $\mathrm{Hb} \mathrm{G}$ Chinese. Shanghai Med J (in Chinese) 5: 125-126, 1982.

7. Blackwell RQ, Weng MI, Liu CS, Shih TB and Wang CL Hemoglobin G Chinese in Chinese subjects in Taiwan. Vox Sang 23: 363-368, 1972.

8. Shih MC, Peng CT and Chang JG: Association of Hb G-Chinese [alpha30 (B11) Glu $\rightarrow$ Gln] with alpha-thalassemia-1 of the Thai type in a Taiwanese family. Hemoglobin 27: 41-44, 2003.

9. Qin WB: Hemoglobinopathy. People's Medical Publishing House, Beijing, 1984.

10. Lin M, Wu JR, Yang LY, Zou HY, Wang Q and Zheng L: Hb Q-H disease: two cases in a Cantonese family. Blood Cells Mol Dis 41: 259-260, 2008.

11. Lin M., Wu JR, Yang LY, Chen H, Wang PP, Wang $Q$ and Zheng L: Hb G-Waimanalo: occurrence in combination with alpha-thalassemia-1 Southeast Asian deletion. Blood Cells Mol Dis 42: 36-37, 2009. 